\title{
Antibody levels in Ethiopian children five years after vaccination with two different doses of hepatitis B vaccine: Is there a need for booster vaccine?
} Edemariam Tsega MD FRCPC PhD, John Horton MD, Erik Nordenfelt MD PhD, B-J Hansson PhD, Belachew Tafesse MD,
Gizachew Wolde-Hawariat BSc, Johan Lindberg MD PhD

E Tsega, J Horton, E Nordenfelt, et al. Antibody levels in Ethiopian children five years after vaccination with two different doses of hepatitis $B$ vaccine: Is there a need for booster vaccine? Can J Gastroenterol 1998;12(1):57-60. It was hypothesized that, following effective initial vaccination, a booster dose of hepatitis $B$ vaccine will not be necessary in areas of hyperendemicity for hepatitis B virus (HBV) infection. A total of 314 Ethiopian children, ranging from two to 14 years old, were alternatively vaccinated with 10 and $20 \mu \mathrm{g}$ hepatitis $B$ vaccine doses, using the initial, one- and six-month schedule. Five years later, 210 of the vaccinees were retested for anti-HBV surface antibody titres. Both 10 and $20 \mu \mathrm{g}$ doses of hepatitis B rDNA yeast vaccine were equally immunogenic and protective against HBV infection for at least five years despite marked reduction of mean antibody levels and geometric mean titres, with $11 \%$ of the vaccinees showing antibodies below the protective level. For firm further recommendations a longer follow-up period of vaccinees is suggested.

Key Words: Booster vaccine, Doses, Ethiopian children, Hepatitis B vaccine
Taux d'anticorps chez des enfants éthiopiens cinq ans après une vaccination au moyen de deux doses de vaccin contre l'hépatite $B$ : le rappel est-il nécessaire?

RÉSUMÉ : Selon l'hypothèse, après une vaccination initiale efficace, une dose de rappel de vaccin contre l'hépatite $B$ ne sera pas nécessaire dans les régions d'hyperendémie d'infections au virus de l'hépatite B. En tout, 314 enfants éthiopiens de 2 à 14 ans ont été vaccinés au moyen de doses de vaccin contre l'hépatite $\mathrm{B}$ de 10 et de $20 \mu \mathrm{g}$ à six mois d'intervalle. Cinq ans plus tard, 210 des patients vaccinés ont été testés de nouveau pour un dosage des anticorps anti-HBV de surface. Les deux doses de 10 et de $20 \mu \mathrm{g}$ de vaccin à levure contre l'hépatite (BrDNA) se sont révélées tout aussi immunogènes et protectrices contre l'infection au HBV pendant au moins cinq ans, malgré la réduction marquée des taux moyens d'anticorps et des moyennes géométriques, $11 \%$ des sujets vaccinés ayant présenté des anticorps sous le taux de protection. Pour une recommandation plus ferme, il faudrait exercer un suivi plus long auprès des sujets vaccinés.

Department of Internal Medicine, Faculty of Medicine, Memorial University, St John's, Newfoundland; SmithKline Beecham International, Brentford, United Kingdom; Section of Clinical Virology, Department of Medical Virology, University of Lund, Malmö General Hospital, Malmö, Sweden; Department of Internal Medicine, Faculty of Medicine, Addis Ababa University and Birla Clinic, Yekatit 12 Hospital, Addis Ababa, Ethiopia; and Department of Infectious Diseases, Ostra Hospital, University of Goteborg, Sweden

Correspondence and reprints: Professor Edemariam Tsega, Memorial University, Newfoundland Regional Health Center, 1 Judges Terrace,

Grand Falls-Windsor, Newfoundland A2A 1L3. Telephone 709-292-2500, fax 709-292-2294, e-mail lestsega@nf.sympatico.ca

Received for publication September 4, 1997. Accepted November 17, 1997 
$E^{t}$ thiopia is one of the hyperendemic areas for hepatitis B virus (HBV) infection. The hepatitis B virus surface antigen $(\mathrm{HBsAg}$ ) carrier state is $8 \%$ to $12 \%$, and the sequelae of HBV infection, chronic hepatitis, cirrhosis and hepatocellular carcinoma account for high morbidity and mortality (1-3).

Unlike in Southeast Asia, in Ethiopia vertical transmission is uncommon, but horizontal transmission occurs early in life within the family setting, and infection continues to rise gradually throughout adult life (4). Thus, although mass vaccination of newborns is an urgent need, the high cost of the available vaccines in third world countries prohibits implementation of such a program. To reduce the cost of the vaccine, the safety and immunogenicity of a rDNA HBV vaccine (Engerix B, SmithKline Beecham) were compared by administering $10 \mu \mathrm{g}$ (group A) and $20 \mu \mathrm{g}$ (group B) doses to two comparable (age and sex) groups of children between two and 14 years of age. Both doses, using the initial, oneand six-month schedule, were shown to be equally immunogenic, with seroconversion rates of $97 \%$ to $100 \%$ and antiHBs geometric mean titres (GMTs) of 3421 to $6336 \mathrm{IU} / \mathrm{L}$ (5) a month after the third dose of vaccine. At the time of the vaccination trial, it was hypothesized that a booster injection of the vaccine after five to 10 years might not be needed because the repeated exposure to HBV in the endemic area could give rise to anamnestic response (ie, production, in response to an antigenic stimulus, of an antibody that has been produced in the host on some previous occasion) and, hence, an indefinite period of protection.

Therefore, determination of anti-HBs levels, five years after the initial vaccination, was planned in groups who received $10 \mu \mathrm{g}$ (group A) and $20 \mu \mathrm{g}$ (group B) of the vaccine, respectively.

\section{SUBJECTS AND METHODS}

Of 380 children (two to 14 years old) screened for HBsAg, antihepatitis $\mathrm{B}$ core $(\mathrm{HBc})$ antigen and anti-HBs, 314 were found to be negative. These noninfected and nonimmune Ethiopian children ( 156 boys and 158 girls) were vaccinated with $\mathrm{rDNA}$ yeast-derived hepatitis $\mathrm{B}$ vaccine using the initial, one- and six-month schedule between October 1987 and March 1988. They did not have acute or chronic disease or a history of allergy to any vaccine preparation. Alternate subjects received either 10 or $20 \mu \mathrm{g}$ of the vaccine intramuscularly into the deltoid muscle (5). The anti-HBs antibody titres and the GMT were determined a month after the first, second and third doses.

Parents of the vaccinees were advised to report to the hospital where they were vaccinated if their child developed jaundice during the ensuing five years. Five years later, during April and May 1993, blood specimens were collected to determine anti-HBs antibody levels. Results were obtained from 210 subjects (67\% of the total 314 vaccinees), despite repeated attempts to contact all of the original vaccinees.

Anti-HBs antibody titres were determined by using the radioimmunoassay method (commercial kits from Abbott Laboratories), as in the authors' original study (5). The $\chi^{2}$
TABLE 1

Levels of antihepatitis B virus surface (anti-HBs) antigen and geometric mean titre (GMT) after one month and after five years of vaccination

\begin{tabular}{ccc}
\hline & $\begin{array}{c}\text { Anti-HBs titre level } \\
(\mathbf{I U} / \mathbf{L})\end{array}$ & $\begin{array}{c}\text { GMT } \\
(\mathbf{I U} / \mathbf{L})\end{array}$ \\
\hline $10 \mu$ g group $(\mathrm{n}=108)$ & & \\
One month after vaccination & $13,458.7$ & 3651.5 \\
$\quad$ Five years after vaccination & 1193.6 & 192.6 \\
$20 \mu$ g group ( $\mathrm{n}=102)$ & & \\
One month after vaccination & $16,834.7$ & 4569.8 \\
Five years after vaccination & 843.6 & 261.2 \\
\hline
\end{tabular}

TABLE 2

Distribution of antihepatitis B virus surface (anti-HBs) antigen titres in recipients of two different doses of hepatitis $B$ vaccine one month and five years after vaccination

\begin{tabular}{|c|c|c|c|c|c|}
\hline & \multicolumn{5}{|c|}{ Levels of titres (IU/L) } \\
\hline & $<10$ & $\begin{array}{l}10- \\
100\end{array}$ & $\begin{array}{l}101- \\
1000\end{array}$ & $\begin{array}{c}1001- \\
10,000 \\
\end{array}$ & $>10,000$ \\
\hline \multicolumn{6}{|l|}{$10 \mu \mathrm{g}$ group $(\mathrm{n}=108)$} \\
\hline $\begin{array}{l}\text { One month after } \\
\text { vaccination }\end{array}$ & 0 & 2 & 26 & 40 & 40 \\
\hline $\begin{array}{l}\text { Five years after } \\
\text { vaccination }\end{array}$ & 16 & 25 & 37 & 27 & 3 \\
\hline \multicolumn{6}{|l|}{$20 \mu \mathrm{g}$ group $(\mathrm{n}=102)$} \\
\hline $\begin{array}{l}\text { One month after } \\
\text { vaccination }\end{array}$ & 3 & 2 & 14 & 34 & 49 \\
\hline $\begin{array}{l}\text { Five years after } \\
\text { vaccination }\end{array}$ & 8 & 17 & 48 & 29 & 0 \\
\hline
\end{tabular}

test was used for comparison where applicable, and the geometric mean and its $95 \% \mathrm{CI}$ were used to describe the average of individual titres.

\section{RESULTS}

A total of 160 subjects ( 85 males and 75 females) in group A and 154 ( 71 males and 83 females) in group B initially completed the vaccination program. Of these, 108 ( 52 males and 56 females) from group A and 102 (43 males and 59 females) from group $B$ were available for retesting after five years. For group A subjects, mean anti-HBs antibody titre and mean GMT of the 108 vaccinees (68\% of the total of 160 initial vaccinees in group A) a month after the third dose were $13,458.7 \mathrm{IU} / \mathrm{L}$ and $3651.5 \mathrm{IU} / \mathrm{L}$, respectively. Five years later, the anti-HBs titre and GMT of these vaccinees were only 9\% (1193.6 IU/L) and 5\% (192.6 IU/L), respectively, of the original values. Similarly, for group B subjects, the antiHBs antibody titre level and the GMT of 102 (66\% of the total 154 initial vaccinees in group B) decreased from $16,843.7 \mathrm{IU} / \mathrm{L}$ and $4569.8 \mathrm{IU} / \mathrm{L}$, to $843.6 \mathrm{IU} / \mathrm{L}$ (5\% of the original titre) and $261.2 \mathrm{IU} / \mathrm{L}$ ( $6 \%$ of the original GMT), respectively (Table 1 ). There was no difference in the mean anti-HBs titres and GMTs between males and females, and no difference in results between those younger and older than eight years of age. 
The distribution of the anti-HBs titres in groups A and B a month after the complete vaccination and five years later are shown in Table 2. Thus, five years after the initial vaccination, there was a significant reduction in the anti-HBs titres in both groups, with 24 subjects below the accepted protective level (10 IU/L) and only three of the original 89 subjects with anti-HBs titre levels greater than 10,000 IU/L (all recipients of $10 \mu \mathrm{g}$ dose).

Three subjects showed an increase in the anti-HBs levels five years after vaccination. All were females older than eight years of age; one was from group A (level increased from 121 to $294 \mathrm{IU} / \mathrm{L}$ ) and two were from group B (4 to $83 \mathrm{IU} / \mathrm{L}, 9$ to $1486 \mathrm{IU} / \mathrm{L}$ ), and the latter two had an anti-HBs titre level of less than $10 \mathrm{IU} / \mathrm{L}$ a month after the initial complete vaccination.

Three vaccinees, two males and one female, all younger than eight years old and with high levels of antibodies initially and five years postvaccination, presented with acute viral hepatitis due to hepatitis A virus (HAV) infection (immunoglobulin [Ig] M anti-HAV-positive). All were icteric and clinically mild. No cases of clinical hepatitis B were identified.

\section{DISCUSSION}

Five years after vaccination, $89 \%$ of the vaccinees (186 of 210) still had protective levels of anti-HBs antibodies, but levels were markedly reduced to about $5 \%$ of the original mean titre and $6 \%$ of the original GMT. Twenty-four vaccinees $(11 \%)$ had anti-HBs levels below the protective level of $10 \mathrm{IU} / \mathrm{L}$; none of these reported icteric illness. Hadler and associates (6) have shown that, five years after vaccination, $10 \%$ to $15 \%$ of vaccinees had 'undetectable' levels of antibody, comparable with our observation above. As shown in Table 2, the distribution of anti-HBs titre levels soon after vaccination and five years later were similar in groups $A$ and $\mathrm{B}$. Thus, the $10 \mu \mathrm{g}$ hepatitis $\mathrm{B}$ vaccine dose is as effective and immunogenic as the $20 \mu \mathrm{g}$ dose for mass vaccination of children.

The use of $5 \mu \mathrm{g}$ of hepatitis $\mathrm{B}$ rDNA yeast vaccine administered to children between three months and 11 years of age at initial dose and one month later has been shown by Lai et al (7) to be as effective as 10 or $20 \mu \mathrm{g}$ of the same vaccine given in three doses, despite lower anti-HBs antibody titres, presumably due to anamnestic responses. If this observation is confirmed by similar studies, the cost of the vaccination could be further and significantly reduced, hence making it more readily available to third world countries. Also, reducing the number of doses from three to two, given at a short interval, could improve compliance.

Antibody levels higher than the initial levels five years after vaccination - as seen in three of our patients - may be due to anamnestic responses. Two of these patients were poor responders because their anti-HBs levels remained under $10 \mathrm{IU} / \mathrm{L}$ a month after three doses of the vaccine, and they were found to have antibody levels of 93 and 1486 IU/L, respectively, at five years. While the rise of anti-HBs level from 9 to $1486 \mathrm{IU} / \mathrm{L}$ is striking, the increase from $121 \mathrm{IU} / \mathrm{L}$ and $41 \mathrm{IU} / \mathrm{L}$, to $249 \mathrm{IU} / \mathrm{L}$ and $83 \mathrm{IU} / \mathrm{L}$, respectively, is not impressive; the latter levels could be due to nonspecific variability or the declining phases of higher levels of anti-HBs following exposure to HBV infection. If this were truly an anamnestic response, it suggests that vaccinees are likely to be protected from HBV infection irrespective of the initial antibody level following vaccination. However, because antibody levels were not determined periodically, as in the study by Lai and associates (7) in whom 11 of 106 children $(10 \%)$ were noted to have anamnestic response, it is difficult to exclude late responses to vaccination or subclinical HBV infection. Alanine aminotransferase, anti-HBc or $\mathrm{HBsAg}$ were not determined periodically or at the time of the last serum collection for anti-HBs. Thus, latent or asymptomatic HBV infection could not be identified. However, the three vaccinees who presented with jaundice had acute HAV infection as determined by positive sera for IgM anti-HAV, while their anti-HBs antibody levels were still high (342, 1070 and 1577 IU/L, respectively).

Although vaccine-induced antibody levels decline steadily over time, and up to $50 \%$ of adult and child vaccinees who respond adequately to vaccine may have low or undetectable antibody levels, immunological memory remains intact for at least seven to nine years $(6,8,9)$. Based on this observation, recommendations from the United States Immunization Practices Advisory Committee state that there is no need for booster dose, and that serological testing to assess antibody level is not necessary in children and adults with normal immune status. Exceptions include hemodialysis and immunocompromised patients (10). Further recommendations will depend on a longer follow-up period of vaccinees.

\section{CONCLUSIONS}

This study confirms that 10 and $20 \mu \mathrm{g}$ doses of hepatitis B rDNA yeast vaccine are equally immunogenic and protective against HBV infection for at least five years despite significant reduction of antibody level and GMT, with $11 \%$ of the vaccinees showing antibodies below the protective level. This is in keeping with our hypothesis that, in hyperendemic areas, anamnestic responses following vaccination would protect against $\mathrm{HBV}$ infection for a long time. While a longer period of follow-up is necessary, it is also advantageous for third world countries to conduct further studies using a $5 \mu \mathrm{g}$ dose of the same vaccine administered twice instead of the currently recommended three doses, in order to improve compliance and reduce the cost of the vaccine.

ACKNOWLEDGEMENTS: This study was financially supported by SmithKline Beecham Laboratories Limited, United Kingdom, and the Swedish Agency for Research Co-operation with Developing Countries (SAREC), Sweden, through the Ethiopian Science and Technology Commission and the Research and Publication Office of Addis Ababa University, Addis Ababa, Ethiopia. We are grateful to the nurses of the Gastroenterology Unit of the Black Lion Hospital, Addis Ababa, for their active participation in the collection of sera initially and five years after vaccination. 


\section{REFERENCES}

1. Tsega E, Mengesha B, Hansson B-G, Lindberg J, Nordenfelt E. Hepatitis A, B, and delta infection in Ethiopia: A serologic survey with demographic data. Am J Epidemiol 1986;123:344-51.

2. Pavlica D, Samuel I. Primary carcinoma of the liver in Ethiopia: A study of 38 cases proved at postmortem examination. Br J Cancer 1970;24:22-9.

3. Tsega E. Hepatocellular carcinoma in Ethiopia: A prospective clinical study of 100 patients. East Afr Med J 1977;54:281-92.

4. Tsega E, Tsega M, Mengesha B, Nordenfelt E, Hansson B-G, Lindberg J. Transmission of hepatitis B infection in Ethiopia with emphasis on the importance of vertical transmission. Int J Epidemiol 1990;17:874-9.

5. Tsega E, Tafesse B, Horton J, et al. Immunogenicity, reactogenicity and comparison of two doses of recombinant DNA yeast-derived hepatitis B vaccine in Ethiopian children. Trop Geog Med 1990;43:220-7.
6. Hadler SC, Francis DP, Maynard JE, et al. Long-term immunogenicity and efficacy of hepatitis B vaccine in homosexual men. N Engl J Med 1986;315:209-14.

7. Lai C-L, Wong BC-U, Yeoh E-K, Lim W-L, Chang W-K, Lin H-J. Five-year follow-up of a prospective randomized trial of hepatitis $B$ recombinant DNA yeast vaccine vs plasma-derived vaccine in children: Immunogenicity and anamnestic responses. Hepatology 1993;18:763-7.

8. Wainwright RB, McMahon BJ, Bulkow RL, et al. Duration of immunogenicity and efficacy of hepatitis B vaccine in a Yupic Eskimo population. JAMA 1989;261:2362-6.

9. Perry GF. Should employees be tested for immunity after hepatitis B vaccination? J Occup Med 1993;35:1081-2.

10. Immunization Practices Advisory Committee. Hepatitis B virus: A comprehensive strategy for eliminating transmission in the United States through universal childhood vaccination. MMWR 1991;40:1-19. 


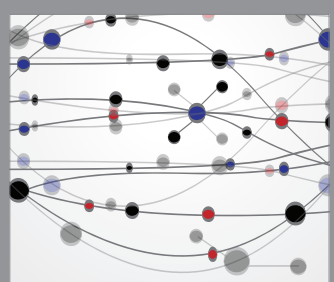

The Scientific World Journal
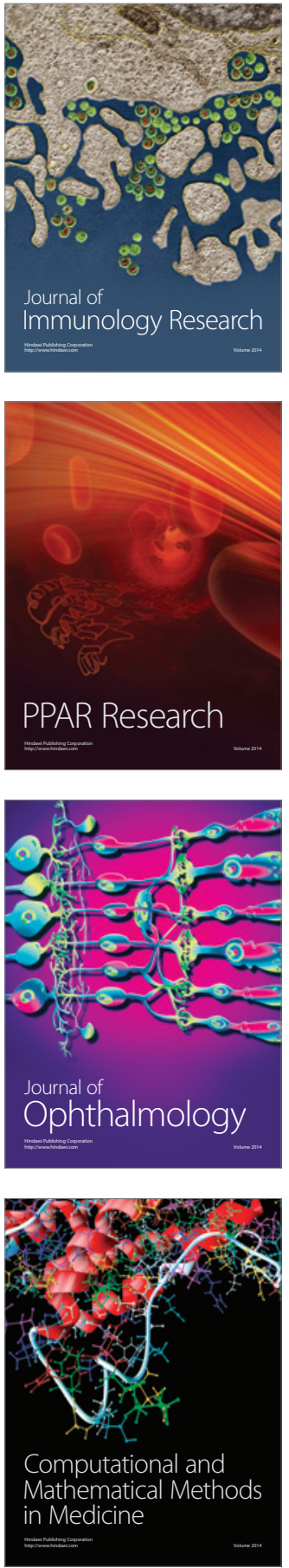

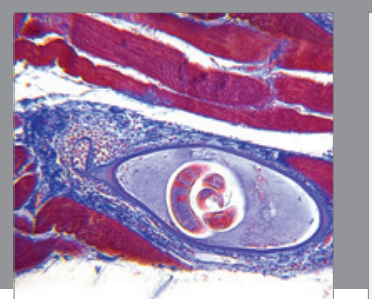

Gastroenterology Research and Practice

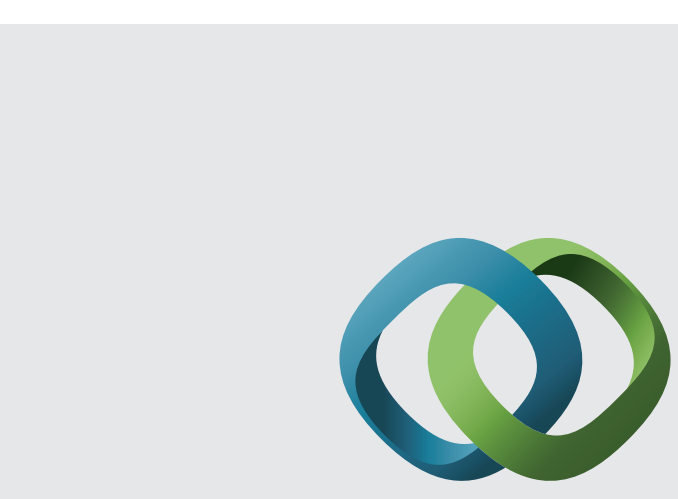

\section{Hindawi}

Submit your manuscripts at

http://www.hindawi.com
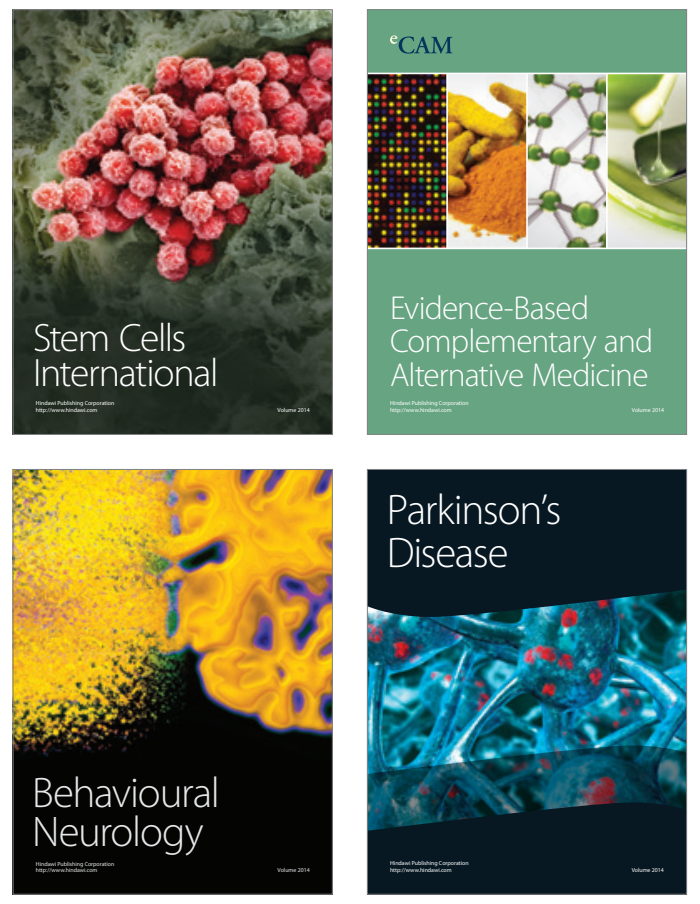
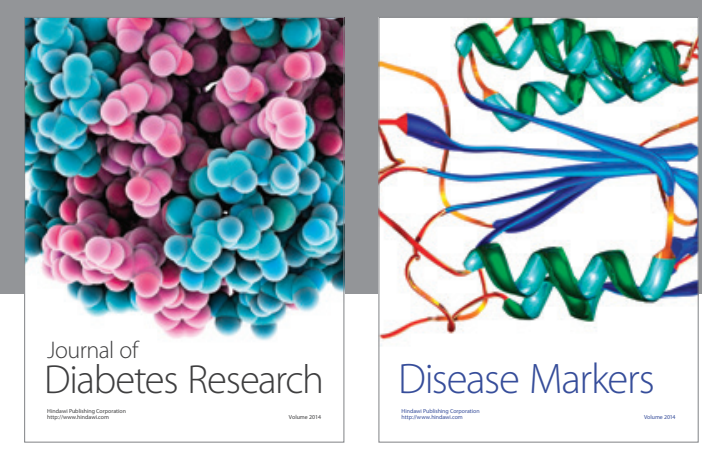

Disease Markers
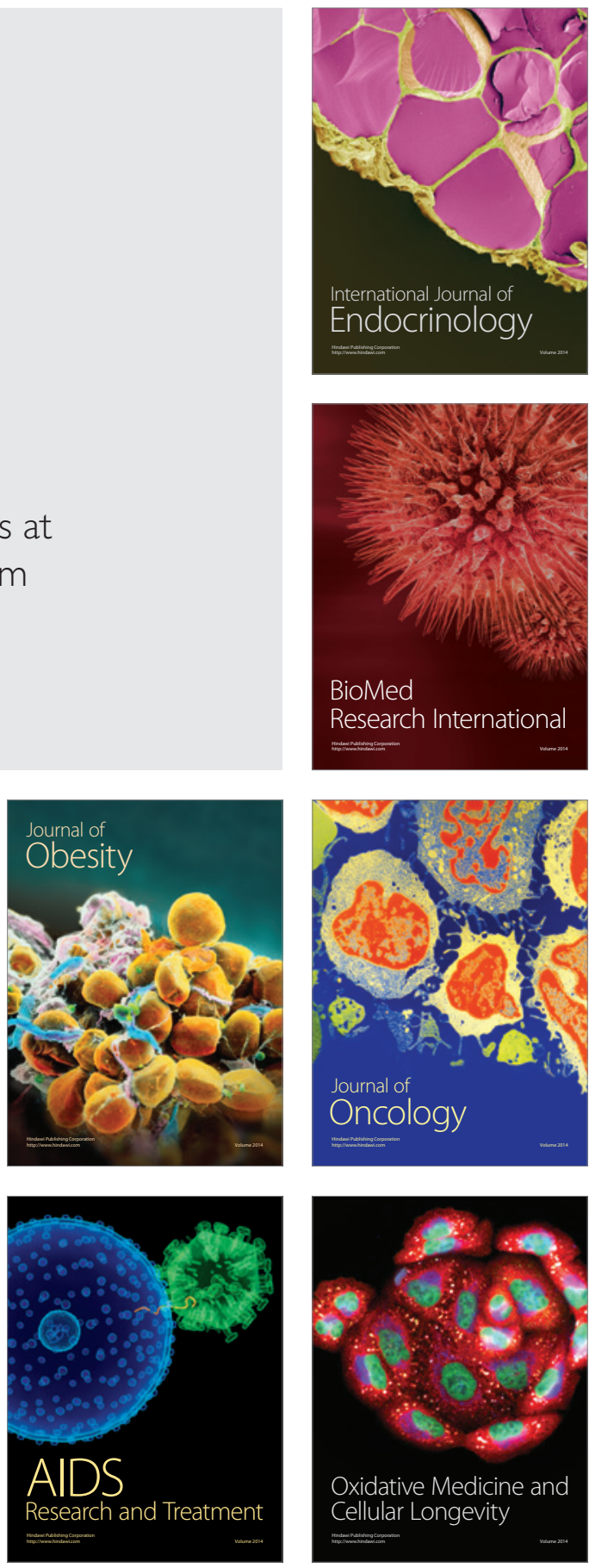